\title{
Determinants of Resource Allocation: Do Bureaucratic Factors Matter?
}

\author{
Maliha Abubakari \\ Graduate School of Public Administration \\ National Institute of Development Administration, Thailand \\ Moo3, Serithai Road, Bangkapi, Bangkok, 10240, Thailand \\ Tel: 66-637-341-872Ｅ-mail: maliha2008@yahoo.com
}

Received: July 13, 2017 Accepted: July 30, 2017

doi:10.5296/emsd.v6i2.11535 URL: https://doi.org/10.5296/emsd.v6i2.11535

\begin{abstract}
Many governments around the world claim to use the normative resource allocation model in the transfer of intergovernmental grants. However, many political-economy studies suggest the contrary. It has been widely suggested that political and economic factors dominate the resource allocation process in both developed and developing countries. Using resource allocation data from the Ghana Education Service, this study supports the arguments that intergovernmental resource allocation transcends the normative principles of proportionality and expenditure need. Political factors do indeed influence resource allocation. One interesting contribution of this study is that, it highlights the importance of bureaucratic factors in the resource allocation process. Bureaucratic representation is a political institutional factor which has to a large extent been neglected by most political economy studies.
\end{abstract}

Keywords: Governmental transfers, Resource, Ghana, Education, Political-economy, Bureaucracy, Politics, Normative principles, Development

\section{Introduction}

The political system is generally the mechanism through which systematic and sound allocation of governmental resources are distributed. There are laid down procedures that guide these distributions to the various sub-governmental units. Like general policy implementation, these distributive processes are not as straight forward as they appear. In other words, the transfer of intergovernmental grants to regional administrative units is not a linear process, it is a highly interactive process. Similarly, these factors that shape the allocative process are a combination of manifest and latent factors. 
The modern state in its current form is comprised of many sub-governmental units spanning different geographic regions. States that are organised under the Federal system of government are even more complex because they do not only cover different spatial units but different autonomous governmental units. This obviously brings forth a new form of dimension to the issue of governmental transfers (Porto and Sanguinetti, 2001). Generally, governments around the world assume a normative posture in the distribution of resources to different jurisdictions across the country. By assuming the normative stands, governments would like to have us believe that the pool of government resources is proportionally distributed among all sub-government units based on factors such as population density/size, expenditure needs of regions or even based on the levels of poverty in the various regions (Rothchild, 1984; Porto and Sanguinetti, 2001; Pearson, 2002; Boex and Martinez-Vasquez, 2005).

However, the normative explanations behind governmental transfers to various sub-governmental units have been heavily contested by recent studies. It has generally been argued that the normative theory on its own cannot fully explain the transfer behaviour of government. That underlining these transfers are politico-economic factors which are normally ignored by the normative explanations. The argument that the administration of governmental grants is politically motivated is supported by a host of extant literature ( $\mathrm{Su}$ and Yang, 2000; Sanguinetti, 2001; Boex, 2003; Boex and Martinez-Vasquez, 2005; Salman, 2007; Abdulai and Hume, 2015; Abdulai, 2016). The empirical studies cited above make it clear that the transfer of governmental resources from the centre to various sub-government units is not only influenced by normative factors but also politico-economic factors.

A common characteristic of almost all political-economy studies which analyse governmental transfers is that they often limit political institutional factors to political representation. In other words, these studies recognise political representation as the single most important political institutional factor which affects governmental transfers. Hardly, would any of those studies mention the significance of bureaucrats in the allocation process. One study that considered the possible influence of bureaucrats in the allocation process was $\mathrm{Su}$ and Yang (2000). The study however, viewed bureaucrats as informal actors who are able to secure resources from the centre for their provinces or regions due to personal ties with political leaders. Extending this role of bureaucrats to the SSA where budgets often run into deficits and where actual funds released are often lower than budgetary allocations (Reinika and Svensson 2004), bureaucrats, especially top level bureaucrats become very important in determining how funds released from the centre should be spent.

Consequently, taking into account the concentration of most political-economy studies in the west and in Latin America, it would interesting to find out if the political-economy determinants of governmental grants is useful in Sub Saharan Africa - SSA since few studies exist in that context. Furthermore, the study seeks to extend political institutional factors to the bureaucracy. Thus, the study seeks examine the effect of bureaucrats on governmental allocations of resources. The study used data from Ghana for the analysis. Ghana is an interesting case for two reasons: First Ghana a unitary state in which the regions (local government units) depend heavily on the central government for the provision of social 
services. Thus, any lopsided allocation of resources would have an effect not only on the distribution of primary public goods across different jurisdiction but development outcomes across different spatial units. Second, Ghana unlike many SSA countries has enjoyed uninterrupted governance for the past twenty-five years with continuous governmental resource allocation. It would be interesting to know how these factors have shaped resource allocation for past twenty-five years.

The rest of the paper is organised as follows. Section 2 discusses normative and political institutional theories of governmental transfers. Section 3 discusses the data used for the study while section 4 presents a descriptive analysis of the results. Section 5 then follow with the conclusion of the study.

\section{Competing Theories: Explaining the Determinants of Intergovernmental Transfers}

\subsection{Normative Theories}

Governments have gone greater lengths to ensure equitable distribution of national resources across population. The desire for equity therefore leads to a more pro-poor and proportional distribution of resources across sub-national government units (Boex and Martinez-Vasquez, 2005). Some African leaders are noted to have made conscious efforts to direct resources at ethno-regional units on the principles of proportionality and extra proportionality. By utilising the principle of proportionality, dominant elites seek to guarantee ethno-regions a fair resource allocation by taking into account the share of population of various regions or groups (Rothchild, 1984; Pearson, 2002). Thus, it is likely for resources to be allocated to a group by virtue of its population density/size. Similarly, with regard to extra proportionality, elites have tried to develop programmes aimed at interregional corrective equity. Such that government might allocate resources to groups/regions on the grounds of poverty levels or levels of deprivation in these regions (Rothchild, 1984; Pearson, 2002; Boex, 2003). Consequently, local governments with greater expenditure needs/poverty levels would most likely receive more government allocations (Boex and Martinez-Vasquez, 2005). Variables that have been used to measure local expenditure needs differ from country to country. However, all studies include commonly used measures such as demographic variables including population density/size, economically dependent population and size of school aged population. This study would not be examining any of these normative factors since most governments manifestly adopt this principle in their allocation process.

Empirically, local expenditure needs generally have a positive impact on government transfers. In Uganda for example, evidence was found in support of population size and human development index. Researchers also found that the concentration of Aids cases (population density) in urban areas drives funding more than factors such as region, poverty and race. Thus, population density tends to influence funding more than even poverty in some jurisdictions. In another study, evidence was found to support the pro-poor allocation of resources to local governments by the central government (Pearson, 2002; Boex, 2003; Salman, 2007). Besides these cases of positive associations, there have also been exceptional cases. In Nigeria for instance, no relationship was found between key expenditure needs and governmental grants and in Mexico there was positive relationship between HDI and 
governmental transfers. In Tanzania, a positive relationship was found between government allocations and local fiscal capacity (Boex, 2003; Boex and Martinez-Vazquez, 2005; Martin, Pollack and Paltiel, 2006).

\subsection{Political-economy Theories}

Many studies have established that the normative explanation of intergovernmental transfers of grants is not only inadequate but consciously making an effort to trivialise political institutional factors. It has therefore been argued that the major weakness of the normative theory is that it ignores current political processes that shape the allocations of governmental resources in many economies (Porto and Sanguinetti, 2001). The influence of political representation on governmental transfers has long be established and recognised in the literature. Early works of Holcombe and Zardkhoohi (1981) hypothesised that the management of federal grants is politically driven, with juicier grants going to states with the most powerful representation in Congress. Similarly, Gradus (1983) linked government transfers to political representation and Atlas et al (1995) found that per-capita federal net-spending obtained by a state was determined by both economic and political-institutional factors.

Most recent studies in jurisdictions such as China, Africa and some other parts of Asia have all pointed to the significance of political factors in shaping resources allocation ( $\mathrm{Su}$ and Yang, 2000; Boex and Martinez-Vasquez, 2005; Shafiullah, 2011; Abdulai and Hulme, 2015; Abdulai, 2016). These empirical findings give credence to the arguments presented by political economy model that unbalanced allocation of government resources is primarily due to differentials in political representation. Although, the arguments put forward by the political-economy theorists are valid, this paper believes that one important political-institutional factor which is believed to exert much influence on the allocation process has not been given due consideration in the literature. The role of bureaucrats in governmental transfers of resources to sub-governmental units has been overlooked by almost all the political-economy studies. The question worth asking is whether bureaucratic factors is not considered a political-institutional factor or probably, researchers have assumed its impact is negligible, thus, the failure to model it into studies?

Bardach (1977) observed that bureaucrats played the budget game but it would appear empirical political-economy studies have not paid much attention to that. To the extent that government programmes succeed at all would largely be due to the bureaucratic form of organisation. Generally, heads of bureaus and many of their subordinates down the line are budget maximisers. They therefore do what they can to win favour in the eyes of officials in the legislature and at the highest political levels of the administration. Consequently, what they do with respect to implementing a particular policy mandate depends largely on the incentives shaped for them by those who control their budget (Bardach, 1977). The preceding description of bureaucrats and what they supposedly do tend to portray bureaucrats as rational actors who can easily have their way with high ranking political leaders.

Su and Yang (2000) in their study pointed out the influence that bureaucrats have over policy and resource allocation. Their study treated bureaucrats as informal representatives but the 
mere acknowledgment of the importance of bureaucrats in the allocation process is a good point to build on. They described bureaucratic agencies as representatives of different economic sectors, persistently lobbying top politicians to extract favourable policies or to maintain their vested interests during redistributive reform. Furthermore, it is argued that a province may get greater access to the centre and its resources through the direct or indirect intervention of central government bureaucrats who were born in the province ( $\mathrm{Su}$ and Yang, 2000). Bureaucrats may not be elected officials and as such they may not have any form of patron-client relations with voters but they do have that natural affinity to the place they call home and would do all that they can to ensure that their home provinces received a fair share of the national cake.

Indeed, bureaucrats are a powerful group of officials in the governance process. There is the continuous debate as to how far bureaucratic officials can go in policy making to channel resources to favoured constituents, to expand agency mandates and budgets or even to act on their personal preferences in ways that deviate from the desires of Congress and the President. Although, several mechanisms such as committee oversight, appropriation hearings and administrative procedures exists to ensure that bureaucrats do not stray very far from original policy intents, it is fair to argue that much doubt remains as to how these mechanisms actually constrain the bureaucracy (Johnson and Libecap, 1994). The preceding paragraph points to the unrestricted powers of the bureaucracy and bureaucrats alike. Thus, if we make conscious attempt to muffle the important role of bureaucrats in policy and governmental transfer process, we do it at our peril. Consequently, this study highlights bureaucrats as one of the key political-institutional factors worthy of examination.

\section{The Data and Methodology}

This section sets out to identify, measure and quantify the variables used in this study. A simple descriptive analysis is carried out using data from Ghana. The data covered the 2004-2016 periods. The basic unit of observation is region/year. Thus, for each variable, there are 13 data points. The variables used in this study include: resource allocation, vote pattern dummy, director dummy and net enrolment ratio. The vote pattern dummy and the director dummy are the explanatory variables, while resource allocation and net enrolment ratio are the explained variables. The rest of the section discusses each of the variables.

\subsection{Resource Allocation}

Resource as used in this study mainly refers to government's annual budgetary allocations. This budgetary transfers are allocated to all government sectors including: administration, economic, infrastructure, social and public safety. The current study limits analysis to the social sector and within the social sector, resource allocation to the education sector is considered. Specifically, the study analyses resource allocation to the Ghana Education Service-GES which is in charge of basic and secondary education. For purposes of this analysis, the budgetary allocations would not be used, rather, actual expenditures would be used. There is the need for a distinction between budgetary allocations and actual expenditure. The amounts that are usually budgeted for are not often the exact amounts released to sub-government units. Actual receipts is not always the same as budgeted amount, they are 
either less or more. Reinika and Svensson (2004) found differences between government budgetary allocation and actual spending. Abdulai (2012) also used actual spending instead of budgetary allocations. Consequently, this study chose to use actual institutional spending as it gives better and more accurate forecast. Furthermore, it is important to mention that only Government of Ghana - GoG allocations were used for the analysis. Therefore, the allocations used for this study does not include donor funds, internally generated funds and other non-GoG funds. Data on actual expenditures of the various regions were gathered from the Ghana Education Service accounts department.

\subsection{Vote Pattern Dummy}

Many political economy studies tend to use political representation as the proxy for polical-institutional factor. Specifically, they tend to represent political factors with per-capita representation (Atlas et al, 1995; Porto and Sanguinetti, 2001; Boex and Martinez-Vazquez, 2005). This study deviates from the status quo by choosing to use vote pattern as a proxy for political representation. Whether a region/province votes for the ruling party or not is a political factor that may have consequences for the amounts of governmental transfers received by the region. This line of argument sits well with the patron-client relations literature. In its simplest term, clientelism describes the selective distribution of benefits to individuals and clearly defined groups in return for political benefits. In modern democracies, patrons or their agents contest for electoral offices and their clients vote them out of general sense of obligation or as part of specific exchange for services rendered or promised (Hopkin, 2006; Hirvi and Whitfield, 2015). Therefore, regions or groups that voted for the ruling party are represented and therefore tend to benefit substantially for their loyalty by way of large transfers from central government. Consequently, a vote for the ruling party is given a value of 1 and 0 for not voting for the ruling party.

\subsection{Director Dummy}

The theoretical literature on the determinants of governmental allocations points to the importance of bureaucratic variables which has been missing in many existing studies. This study therefore makes an effort to examine the effect of bureaucrats on governmental allocation by quantifying bureaucratic influence through the creation of a dummy variable. Johnson and Libecap (1994) identified three types of bureaucrats including political appointees, senior career officials and rank and file career employees. The type of bureaucrats this study refers to are the senior career officials. There are many influential positions within the senior career officers with the ability to influence policy or resource allocation. One of the limitations of this study however, is its inability to examine all of these influential positions. The Ghana Education Service is headed by a director general, so the study tries to examine how the leadership of the director general plays out in the resource allocation process by creating the director dummy variable. Consequently, if the director general for a particular year, e.g. 2004 is from region 'A', region 'A' for the year 2004 takes a value of 1 and other regions take a value of 0 . Information on the director generals were collected at the Ghana Education Service.

It is important to point out that our data for the director dummy variable is seriously 
constrained in the sense that out of 130 observation, the observation (0) recorded 117 while the observation (1) recorded only 13 observations. We are therefore sceptical about the results of such skewed observations. Consequently, we decided to do a further analysis using only one of the regions (Central Region) which has quite an even share of observation for the director dummy. Out of the 13 observations for the region (0) recorded 6 observations and (1) recorded 7 observations. Logically, we try to argue deductively that if the other regions had similar even observations, the results obtained for the central region would have been replicated for the rest of the regions. Thus, what is observed at the sub-national level is a reflection of what pertains at the national level.

\subsection{Net Enrolment Ratio in Basic Education}

Although, the study wants to find out the influence of bureaucrats on governmental allocations, it would be good to know how such allocations impact on enrolment since we are using resource allocation for the education sector. Interesting linkages between resource allocation and educational outcomes would help the study make interesting forecast on government policy and how that impacts development. Primary and secondary school attainment in particular have been argued in the literature to have profound impact on poverty reduction (Easterly, 2002; Songsore, 2003; Higgins, 2009). Net Enrolment Ratio-NET are pre-calculated figures which are lodged in the Education Management Information Systems-EMIS of the Ghana Education Service. It is accessible on the Ghana Education Service website.

\section{Results from Descriptive Analysis}

The paper set out to extend analysis of political-economy determinants of resource allocation with a particular intent to highlight the importance of bureaucratic institutional factors which seem to have received little attention in the literature. The resource allocation data used for this study is from the Ghana Education Service - GES. Like all other government institutions, the GES claims to use the normative resource allocation model in the transfer of governmental resources from the headquarters to the various districts/regions. Interaction with the Budget Officer of GES in order to acquire a better understanding of their allocation model revealed that allocations at the GES were based on equity and efficiency grounds (normative model). In the words of the budget officer:

"The resource allocation model that we have, we allocate a percentage of our resources based on the disadvantage criteria that we have and I will explain. We try to skew resources in favour of districts with low deprivation index ..."

Clearly, according to the budget officer, the GES strictly allocates resources using the normative principles of proportionality and expenditure need. Their allocation model does not allow political institutional factors to influence transfer of resources. However, our descriptive analysis of the GES allocations points to the contrary. Below is a table that presents information on the effect of vote pattern on resource allocation. 


\section{Macrothink}

Table 1. Results for Effect of Vote Pattern on Resource Allocation

\begin{tabular}{|l|l|l|l|l|}
\hline variables & Not Ruling Party (obs) & Mean & Ruling Party (obs) & Mean \\
\hline Resource & 49 & 0.000000012 & 80 & 0.000000024 \\
\hline Basic Net & 49 & 57.19 & 81 & 65.54 \\
\hline
\end{tabular}

From table 1, 49 observations were recorded for regions that did not vote for the ruling party and 80 observations recorded for regions that voted for the ruling party. The corresponding mean governmental resources that went to regions that did not vote for ruling party and the regions that voted for the ruling party are 0.000000012 and 0.000000024 respectively. Clearly, regions that vote for the ruling party received more resources than those that did not vote the ruling party. This result supports the political economy arguments that regions that are represented receive more resources than those that have lower representation.

However, it can be argued that the above results should be expected since the number of observations recorded for the 'ruling party' is twice the observations recorded for 'not ruling party'. Thus, those regions received more resources not because they voted for the ruling party but because of the high observations in that category. However, a careful look at the graphs below from the same data gives a clearer picture and it thus seems the allocations supports the political economy arguments than it supports the normative arguments.

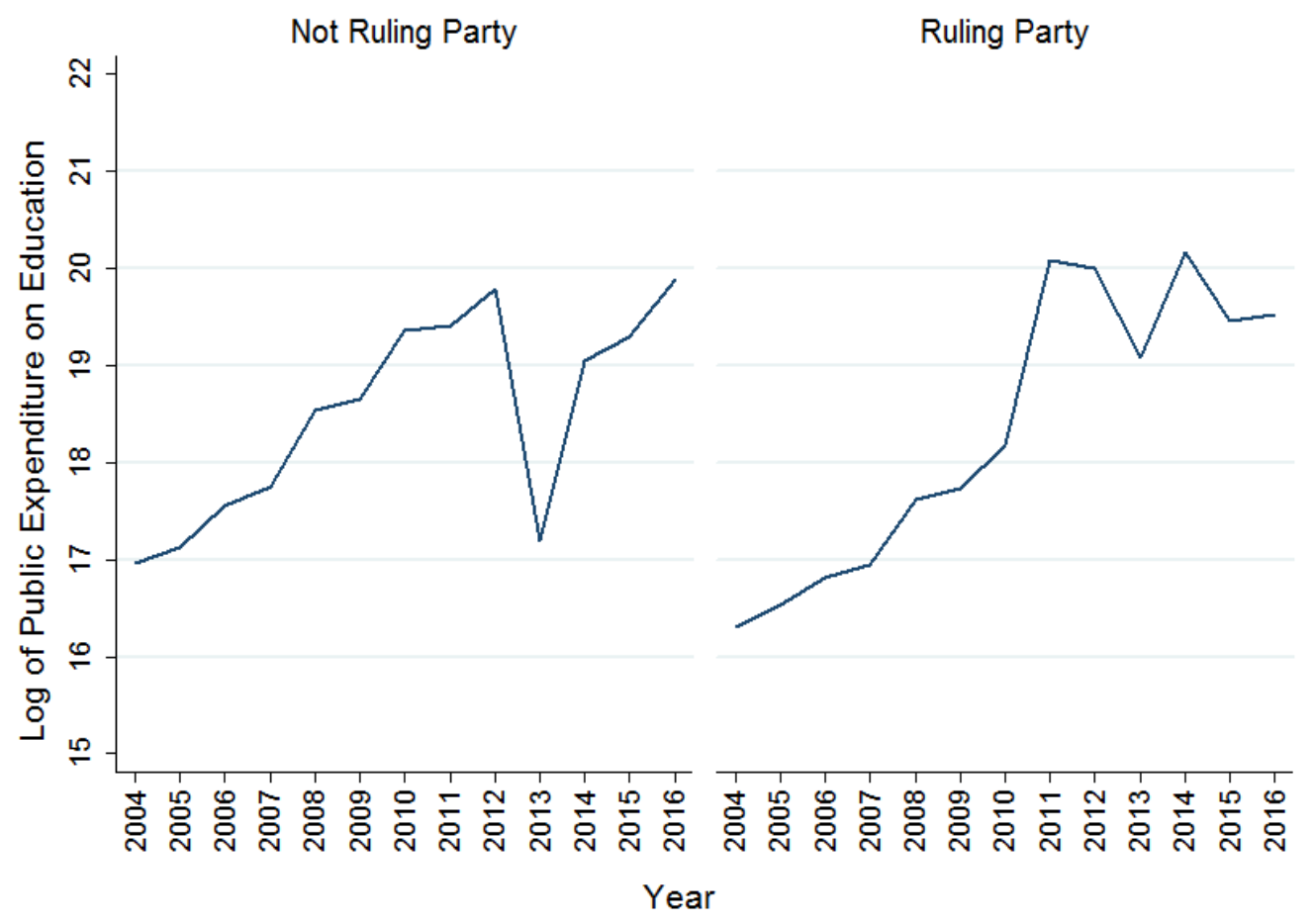

Figure 1. Effect of Vote Pattern on Resource Allocation

An observation of the graphs above indicate that from 2004-2008, both regions that voted for the ruling party and those that did not vote for the ruling party recorded some steady increases in resources but it can be observed that allocations to the regions that voted for the ruling party is much steadier than in regions that did not vote for the ruling party. From 
2009-2011 a sharp increase in allocations to 'Ruling Party' regions is observed but same cannot be said for regions that did not vote for the ruling party. In 2012 however, both 'not ruling party' and 'ruling party' regions witnessed a sharp decline in allocation but the interesting observation is that the decline in the regions that did not vote the ruling party was almost three times the decline observed in regions that voted for the ruling party. All these dynamics in the allocations to both 'Not Ruling Party' and 'Ruling Party' regions lends support to the arguments that political economy factors are important determinants of governmental transfers. The fact that this data is from the Ghana Education Service is an indication that the so called normative allocation criteria used by the GES is not completely objective after all, indeed, there are some political economy undertones to the allocation model of the GES.

Empirical studies supporting the above results are quite appreciable. In an analysis of a comparative study of twelve countries, evidence was found in virtually all the twelve countries that disproportionate political representation gave rise to consistent intergovernmental transfers (Boex \& Martinez-Vazquez, 2005). Findings of Atlas et al (1995) suggested that per capita federal net spending of states was determined by both economic and political factors. Similarly, Porto and Sanguinetti (2001) found that over represented jurisdictions both at senate and at lower chamber have obtained on average higher resources from national government compared to less represented regions. In China it is reported that a province that enjoy greater representation on the Communist Party Central Committee is likely to have more resources allocated to that province from central government (Su and Yang, 2000). Most recent studies and more importantly in other parts of Asia and in Africa have found similar results that support the significance political factors in the resource allocation process (Shafiullah, 2011; Kramon and Posner, 2013; Abdulai and Hulme, 2015; Abdulai, 2016).

Having discussed one aspect of political-economy factors, it is now time to turn attention to near forgotten aspect of the political-economy theory namely bureaucratic factor. Table 2 presents information on the effect of bureaucrats on resource allocation.

Table 2. Results for Effect of Bureaucrat on Resource Allocation (National)

\begin{tabular}{|l|l|l|l|l|}
\hline variables & No Bureaucrat (obs) & Mean & Bureaucrat (obs) & Mean \\
\hline Resource & 116 & 0.0000000171 & 13 & 0.0000000427 \\
\hline Basic Net & 117 & 61.25 & 13 & 73.8 \\
\hline
\end{tabular}

From table 2 it can be observed that the number of observations for regions with no bureaucratic representation is highly disproportional to the regions with bureaucratic representation. Observation for regions with bureaucrats is only 13 while observation for regions with no bureaucrats is 116. Surprisingly, the mean allocations to regions with bureaucrats with only 13 observations is twice the allocation to regions with no bureaucrats. 0.0000000427 and 0.0000000171 for regions with bureaucrats and regions with no bureaucrats respectively. An indication that bureaucratic representation matters, thus, regions that are lucky to have bureaucrats at the top are likely to receive more resources than regions that do not have bureaucratic representation. 
As a result of the skewed observations between regions with bureaucrats and regions with no bureaucrats, we decided to analyse one region (Central Region) that appears to have a near even observation to see if bureaucratic representation will still have an impact on allocations. Table 3 below shows results for the observation.

Table 3. Results for Effect of Bureaucrat on Resource Allocation (Central Region)

\begin{tabular}{|l|l|l|l|l|}
\hline variables & No Bureaucrat & Mean & Bureaucrat & Mean \\
\hline Expenditure & 6 & 0.000000043 & 7 & 0.000000068 \\
\hline Basic Net & 6 & 71.58 & 7 & 73.8 \\
\hline
\end{tabular}

The result for the Central Region is similar to what was observed for the entire country in table 2. Bureaucrats are still important as their impact on resource allocation is high for regions with bureaucrats than regions with no bureaucratic representation at the top level. The results here gives support to both existing theoretical and empirical literature that bureaucrats are important in the intergovernmental allocation process (Bardach, 1977; Johnson and Libecap, 1994; Su and Yang, 2000). Also, Grossman (1992) asserted that the size of a state's bureaucracy and union membership leads to greater grants to the state.

Furthermore, a careful look at both tables 1 and 2 show that information on net enrolment has been added to the analysis. The reason for that addition was to paint a bigger picture about the role of resource allocation in the development process. Most studies that seek to explain the nature and dynamics of intergovernmental transfers tend to view such analyses as end in itself. However, this study views the analysis of determinants of intergovernmental transfers as a means to an end. These transfers are not done in a vacuum, rather they are means to furthering the provision of social services at the local government level. Thus, disproportionate allocations of resources due to political representation have consequences on the provision of these social services as well as development outcomes at the local levels.

Since the resource data used for this study is from the education sector, the study tried analyse the impact of such allocations on educational attainment. Consequently, the impact of resource allocation on net enrolment ratio in basic schools was analysed. From Table 1 it is observed that higher resource allocations translate into higher enrolment ratio in basic schools. The same conclusion can be drawn from table 2. Thus, representation, whether political or bureaucratic leads to higher resource allocations which in turn leads to higher educational attainment. Such findings have serious implications for both inclusive development and poverty reduction. Empirically, it has been established that development disparity across regions is the result of unbalanced distribution of national resources due to unequal representation in politics (Gradus, 1983; World Development Report, 2006; Abdulai and Hulme, 2015; Abdulai, 2016).

\section{Conclusion}

This study set out to examine the effects of political-economic factors on governmental transfer of resources. Particularly, the study sought to highlight the seeming neglect of bureaucracy as an important political-institutional factor which has the potential of exercising control over governmental transfers. Using resource allocation data from the Ghana 


\section{$\triangle$ Macrothink}

Education Service - GES, the study found that even though, the GES manifestly employs normative principles of proportionality and deprivation criteria in its allocative process, the normative principles alone do not satisfactorily explain the allocation model of the GES. Our descriptive analysis reveals that political-institutional factors are equally important in explaining the resource allocation process of the GES. Vote pattern which is used as a proxy for political representation and key bureaucratic positions such as the director general tend to be associated with resource allocation.

The study also found that resource allocation in turn affects enrolment in basic schools. A finding that has important ramifications for inclusive and sustainable development and poverty reduction efforts. Thus, the more representation (political or bureaucratic) a region has, the higher the resources that would be allocated to them from the center which in turn impacts on development (in the case of this study, enrolment). Educational attainment has been widely linked to human development, poverty reduction and economic growth. To the extent that resources are skewed to the political base of elite' means those groups will advance at the expense of unrepresented groups.

However, it is important to caution readers to interpret the findings of this study with caution for the following reasons: first, the data on bureaucratic representation is highly scanty taking into consideration the timeline under review 2004-2016 - only 13 years. This timeline is very short which means very few regions would have had the privilege of having the director general originating from the region. Consequently, most of the regions recorded the same observation for the 13 year period, e.g. a region can record a dummy (0) throughout the 13 years which makes comparative analysis very difficult. Second, the use of the position of the director general as a proxy for bureaucratic representation is very narrow. There are many positions in the bureaucracy that wield more or equal influence as the director. These positions were not included in the study due to the difficulty in tracing such positions into the past. Finally, the study was purely descriptive and also narrowly limited to the Ghana Education Service. Consequently, no generalisations can be made and as such claims of causality cannot be made.

Notwithstanding these limitations, the findings of the study still remain important and though claims of causality cannot be made, important associations have been established especially between bureaucratic representation and resource allocation. In deed there cannot be smoke without fire, the mere establishment of a linkage between bureaucratic representation and resource allocation is enough for researchers to develop interest in that area. Researchers can conduct large scale studies as well as inferential statistical studies into the possible effects bureaucratic factors may have on resource allocation.

\section{References}

Abdulai, A. (2012). State Elites and the Politics of Regional Inequality in Ghana. A Thesis submitted to the University of Manchester for the degree of Doctor of Philosophy in the Faculty of Humanities, UK.

Abdulai, A., \& Hulme, D. (2015). The Politics of Regional Inequality in Ghana: State Elites, 
Donors, and PRSPs. Effective States and Inclusive Development Research Centre (ESID), Development Policy Review, 33(5), 529-553. https://doi.org/10.1111/dpr.12124

Abdulai, A. (2016). The Political Economy of Regional Inequalities in Ghana: Do Political Settlements Matter? European Journal of Development Research, 29(1), 2013-229. https://doi.org/10.1057/ejdr.2016.11

Atlas, C. M., Gilligan, T. W., Hendershott, R. J., \& Zupan, M. A. (1995). Slicing the Federal Government Net Spending Pie: Who Wins, Who Loses and Why. The American Economic Review, 85(3), 624-629.

Bardach, E. (1977). The Implementation Game: What Happens After a Bill Becomes a Law. Cambridge, Massachusett, and London, England, MIT Press.

Boex, J. (2003). The Incidence of Local Government Allocations in Tanzania. Public Administration and Development. 23, 381-391. https://doi.org/10.1002/pad.289

Boex, J., \& Martinez-Vazquez, J. (2005). The Determinants of Incidence of Intergovernmental Grants: A Survey of the International Experience. Andrew Young School of Policy Studies Research Papers Series. Working Paper, 06-52.

https://doi.org/10.2139/ssrn.902454

Easterly, W. (2002). The Elusive Quest for Growth: Economists' Adventures and Misadventures in Tropics. United States of America, Massachusetts Institute of Technology Press

Gradus, Y. (1983). The Role of Politics in regional Inequality: The Israeli case, Annals of the Association of American geographers, 73(3), 388-403.

Grossman, P. J. (1994). A Political Theory of Intergovernmental grants'. Public Choice, 78, 295-303. https://doi.org/10.1007/BF01047760

Higgins, K., Bird, K., \& Harris, D. (2010). Policy responses to the spatial dimensions of poverty. Overseas Development Institute Working Paper 328.

Hirvi, M., \& Whitefield, L. (2015). Public-Service Provision in Clientelist Political Settlement: Lessons from Ghana's Urban Water sector. Development Policy Review, 33(2), 135-158. https://doi.org/10.1111/dpr.12095

Holcombe, R. G., \& Zardkhoohi, A. (1981). The Determinants of Federal Grants. Southern Economic Journal, 48, 393-399. https://doi.org/10.2307/1057939

Hopkin, J. (2006). Conceptualising Political Clientelism: Political Exchange and Democratic Theory. Paper Prepared for APSA Annual Meeting, Philadelphia, 31 August.

Johnson, R. N., \& Libecap, G. D. (1994). The Federal Civil Service System and the Problem of Bureaucracy. USA, University of Chicago Press.

https://doi.org/10.7208/chicago/9780226401775.001.0001

Kramon, E., \& Posner, D. N. (2013). Who Benefits from Distributive Politics? How the 


\section{Macrothink}

Environmental Management and Sustainable Development

ISSN 2164-7682

2017, Vol. 6, No. 2

Outcome One Studies Affects and Answer One Gets. American Political Science Association, 11(2). https://doi.org/10.1017/S1537592713001035

Martin, E. G., Pollack, H. A., \& Paltiel, A. D. (2006). Fact, Fiction, and Fairness: Resource Allocation Under the Ryan White CARE Act. Health Affairs, 25(4), 1103-1112.

https://doi.org/10.1377/hlthaff.25.4.1103

Pearson, M. (2002). Allocating Public Resources for Health: Developing Pro-Poor Approaches.

Porto, A., \& Sanguinetti, P. (2001). Political Determinants of Intergovernmental Grants: Evidence from Argentina. Economics and Politics, 13(3).

https://doi.org/10.1111/1468-0343.00092

Reinnika, R., \& Svensson, J. (2004). Local Capture: Evidence from a Central Government Transfer Programme in Uganda. The Quarterly Journal of Economics, 119(2), 679-705. https://doi.org/10.1162/0033553041382120

Rothchild, D. (1984). Middle Africa: Hegemonial Exchange and Resources Allocation in Groth, A.J. and Wade, L. L. (Eds), Comparative Resource Allocation: Politics, performance and policy Priorities. Beverly Hills, Sage Publications.

Salman, A. (2007). Pro-Poor Budget Allocations in Local Government System. South Asia Partnership - Pakistan.

Shafiullah, M. (2011). Foreign Aid and Its impact on Income Inequality. International review Business Research Papers, 7, 91-105.

Songsore, J. (2003), Regional development in Ghana: The theory and the reality. Accra, Woeli Publishing Services.

Su, F., \& Yang, D. L. (2000). Political Institutions, Provincial Interests and Resource Allocation in Reformist China. Journal of Contemporary China, 9(24), 215-230. https://doi.org/10.1080/713675934

World Bank (2006). World Development Report: Equity and Development, Washington, DC: World Bank.

\section{Copyright Disclaimer}

Copyright for this article is retained by the author(s), with first publication rights granted to the journal.

This is an open-access article distributed under the terms and conditions of the Creative Commons Attribution license (http://creativecommons.org/licenses/by/3.0/). 